\title{
INFORMATION AND CONSULTANCY CENTRES IN SLOVAKIA - PROMOTING PARTNERSHIP IN COHESION POLICY
}

\author{
Igor Jašurek ${ }^{1}$
}

DOI: https://doi.org/10.31410/LIMEN.2020.141

\begin{abstract}
Implementation of cohesion policy, as the major EU budgetary chapter, is subject to vast scholarship. Therefore, surprisingly enough, the principal-agent ( $P$-A) framework has received little recognition in this academic field so far. The present paper contributes to the expansion of this increasingly popular approach also into cohesion scholarship by examining the operation of Information and Consultancy Centres (ICC) in Slovakia. The major finding shows limits of the P-A framework by suggesting that instead of a mutual conflict, it is a cooperative mode dominantly shaping dynamics of $P$-A relations due to the shared goals and interests. ICC operations and relations with the Government are interpreted via observational equivalence and ceremonialism as the recognized $P$-A framework tools.
\end{abstract}

Keywords: ICC, Principal, Agent, Uncertainty costs, Observational equivalence, Ceremonialism.

\section{INTRODUCTION}

7 his paper attempts to expand the scope of studying micro-delegation (Delreux and Adriaensen, 2017) meaning P-A relations under an individual EU policy area such as cohesion policy. Thus, the paper contributes to the limited scholarship employing the P-A framework in cohesion policy which by now focuses mostly on control mechanisms in implementation (Blom-hansen, 2005; Bachtler and Ferry, 2013). In this research, an alternative perspective on dynamics of P-A relations is adopted. Instead of being conflict propelled, the paper explains why partnership prevails in the P-A relations. By adopting this perspective, the paper also reveals methodological pitfalls of the P-A framework. On top of that, using the primary sources only, constituting of official releases from the ICC and the Government, sets methodological limits on the scope of the study as it leaves aside a broader portfolio of stakeholders who may be a source of valuable inputs on the P-A relations examined by means of e. g. qualitative methods such as structured interviews or surveys. Nevertheless, the paper presents a consistent analysis of the ICC operations via the P-A framework with noteworthy findings relevant for studying the limits of the P-A framework. The major finding of the paper suggests that the cooperative mode between the ICC and the Government dominantly shapes the dynamics of the P-A relations rather than their mutual conflict. This is due to the shared goals and interests between the ICC as the agent and the Government as the principal which are determined by the political context. P-A relations are interpreted through the recognized PA framework tools of observational equivalence and ceremonialism. Cooperation between the principal and the agent fosters mutual partnership ties which are in the end beneficial for both actors. The paper is structured as follows. The first part outlines the application limits of the partnership principle. The second part introduces the theoretical foundations of the P-A framework. In the third part, major aspects of ICC operations are depicted in order to interpret

1 Faculty of National Economy of the University of Economics in Bartislava, Dolnozemská cesta 185235 , Slovakia 
them via the P-A framework in the fourth part. The concluding fifth part summarizes the main arguments and methodological limitations.

\section{APPLICATION LIMITS OF THE PARTNERSHIP PRINCIPLE}

The partnership is one of the founding principles in cohesion policy since its birth in 1988. By providing an organisational platform for engaging different stakeholders in programming and implementation, partnership touches the heart of cohesion policy. Barca in his Report for the European Commission (2009) tellingly expresses this idea when regarded partnership a vehicle for mobilisation of public and private actors' expertise and experience (p. 100). Thus unsurprisingly, partnership is "an idea whose time has come" (Bache, 2010, p. 58). Yet, its application significantly varies across the EU and has become subject to recurrent criticism. Despite its increasing importance over decades and strengthening its institutionalisation (Bachtler and McMaster 2009), partnership suffers of "mistrust and misgivings among the involved actors about the perceived strategies of the administrative and societal partners" (Bauer, 2002 p. 783). This is for example a consequence of the undeveloped accountability of non-state actors for different implementation phases as well as the Commission limited advocacy role on behalf of a more active pursuit of partnership (Polverari and Michie, 2009). Consequently, control over implementation is left at discretion of member states excelling in their gatekeeping role (Bache, 1999). And this has not changed much with the last cohesion reform in 2013 which on one hand brings substantial reinforcement of the principle of partnership being binding for overall programming exercise including preparations of operational programmes and partnership agreements. And on the other hand, the partnership is regulated by means of the Commission regulation (Commission Delegated Regulation, 2014). However, the Commission falls short of devising its regulatory control mechanisms to monitor an application of partnership which again leaves room for member states and their individual approaches in pursuit of partnership without pressures from the Commission. At the same time, there is wide room for exploring the untapped potential for advancing partnership in different national and subnational contexts.

As the principle of partnership is applicable across hierarchically organized patterns of cooperation, the ICC as means to apply partnership are particularly interesting subject to study relations in a public policy environment. First of all, it is however necessary to explain the rationale for employing the P-A framework as a convenient analytical tool to examine ICC. Even more so in the light of the fact that the P-A framework, though not completely new to cohesion policy, is far from being a conventional tool in studying this major chapter in the EU budget. The following part outlines the main characteristics of the P-A framework relevant for the present analysis of the ICC operation.

\section{P-A FRAMEWORK}

The P-A framework origins in microeconomics exploring hierarchical relations between firm owners (principals) and managers (agents) in ensuring that the pursuit of the former's interest represents the highest operational imperative for the latter. This premise stemming from a dyadic relation relying on the acts of delegation and its subsequent control then gives rise to the scholarship applying the framework also in studying public administration (Shavell, 1979; Moe, 1984; Perrow, 1986) and US congressional politics in particular (McCubbins and Schwartz, 1984; Epstein and O'Halloran). With Pollack's seminal work (1997), the P-A framework also enters the field of EU studies and integration theories demonstrating promises and shortcomings in interpreting policy making at the European level (Kassim and Menon, 
2003). Taken from this perspective, it is somewhat surprising that the P-A framework has so far found a limited employment in the area of cohesion policy as the major chapter in the EU budget. As already noted, the existing accounts focus on control mechanisms in implementation (Blom-hansen, 2005; Bachtler and Ferry, 2013).

As stated above, delegation and control are the building components of the P-A framework. Hierarchy presents a basis for a functional interpretation of a dyadic relation through a formal contract and its tools. In this way, the P-A framework is rather theory-neutral (Dür and Elsig, 2011 , p. 331). The primary reason for delegation is principal's lacking capacity to carry out specific tasks. Therefore, the principal authorizes the agent to engage in these tasks at his own discretion. Taken from this perspective, the principal plays an entrepreneurial role as he has authority to establish a service provider (agent) and delegate specific tasks upon him.

Traditionally, the P-A approach assumes that principal's lacking performance capacity as a reason for delegation translates into his disadvantage. Simply, the agent has more task specific information resulting in an information asymmetry, at the expense of the principal. Therefore, the principal has to devise mechanisms to control agent's potentially excessive arbitrary or opportunistic behaviour. Derails in agency is called agency loss (Pollack, 1997), slack (Delreux and Adriaensen, 2017) or shirking (Kassim and Menon, 2003). Inevitably, cost incurred to put in place efficient control mechanisms shall not override benefits of delegation for the principal. Therefore, the principal has to properly balance efficiency of control mechanisms to minimize agent's opportunistic behaviour and overall cost of agency.

Little attention is, however, paid to the fact that actually both, principal and agent, are opportunity seekers and rational utility maximisers (Sobol, 2015). This means that as much as the agent act opportunistically, the principal can also be calculative. Such complexity in their relations was addressed already by Perrow (1986) who tellingly noted that P-A theorists "almost invariably assume that it is the agent that is opportunistic, even to the point of cheating, rather than the principal" (p. 14). This does not necessarily lead to "pathological delegation" where the agent is hindered by the inimical principal (Sobol, 2015). More importantly, agency and dynamics of P-A relations often takes place in the context which is highly political, a point though underappreciated, is already addressed elsewhere (Hawkins and Jacoby, 2009). Therefore, results of agency are at best difficult to predict or in the worst-case scenario, they come with high political costs. Furthermore, through delegating new agency, the principal incurs also uncertainty costs (Hawkins and Jacoby, 2009) expressing burden of unfamiliarity with the new agent whose operational skills are unknown to the principal at the start of agency as is also efficiency of established control mechanisms. Such uncertainty is, however, also on the part of the agent who may not be sufficiently familiar with principal's intentions and motivations as well as with his managerial skills. Public administration is particularly exposed to these dilemmas and their impacts. Thus, both actors share uncertainty costs, notably in the form of a reputation risk. Therefore, both aim at reducing such risk. To launch a reformed measure in public administration, such as the ICC operation is an opportunity as much as a risk in the P-A relations. As the paper shows, the P-A ultimate strategy is maximisation of the former and reduction of the latter and this is the point where interests of the principal and the agent meet and align. This is a subject of the part interpreting the ICC operation via P-A framework. Let's first depict the aspects of ICC operations. 


\section{ICC IN SLOVAKIA}

Established in 2016, the ICC addresses the issues of visibility and awareness of EU funding opportunities at the regional level by providing free of charge consultancy and information dissemination. The aim is to encourage new applications for grants and to increase the number of approved projects and thus further stimulate territorial development. Their operation is financed from national technical assistance. Before going any further, it is important to note why the issue of the ICC operation is a relevant subject to study. There is not only an obvious explanation linking EU funding opportunities to territorial development. More importantly, this is a domain of public policy which even demonstrates a continuation over political cycles. Founded in 2016, the ICC have not only survived the changing government representations after the general elections in 2020. The agenda of free-of-charge territorial-based consultancy and targeted information dissemination on EU funding gains new momentum. The government in its Manifesto commits to engage the already existing infrastructure of informationconsultancy centres into consultancy and project preparation (Programové vyhlásenie Manifesto, 2020). This signals that willingness of the newly formed Government to continue with the ICC operation is a politically convenient approach with a perceived positive impact on public attitudes.

Foundation of the ICC was initiated in 2016 by the Deputy Prime Minister's Office for Investments and Informatization (DPMO) responsible for the overall coordination of programming and implementation of the EU funds in Slovakia. The decision was partially motivated by the results from the assessment of administrative burden among applicants and beneficiaries of the EU funds as part of national ex post evaluation of the 2007-13 programming period (Zhodnotenie administratívnej zát'aže -Assessing administrative burden, 2013). The results e.g. show that potential applicants are discouraged by overgeneralized nature of otherwise easily accessible information lacking also more practical value. At the same time, applicants would also appreciate more personalized consultation services including workshops on calls for grant applications. Having in mind these results, DPMO coordinates municipalities in founding the ICC at the level of 7 regional seats and 1 district seat. Municipalities offer own premises for the ICC operation. As founders, they are also held accountable for ICC staffing (4 employees per Centre), material resourcing and overall operation. ICC foundation is based on the legally binding partnership contracts between the DPMO and the individual regional or district municipalities laying down coordination responsibilities (DPMO) and delegated responsibilities (municipality). As already noted, all operational costs are covered from the EU funds.

DPMO regulates the ICC operation straight from the beginning by means of the Guidance (Metodický pokyn č. 25 - Methodology Guidance no. 25, 2019). It determines ICC establishment in terms of staff selection procedures and its publicity as well as listing activities and their monitoring. Guidance also stipulates a framework of cooperation between the ICC and the Managing Authorities in order to ensure a smooth conduct of ICC activities. At the same time, the Guidance lays down the ICC responsibilities towards their coordinator, DPMO, notably biannual reporting on their activities in the prescribed format. ICC reports typically include summarization of their information dissemination and consultancy activities, campaigns, workshops and seminars, cooperation with the implementation bodies and publicity. On top of that, the ICC also collect and analyse feedback from all clients and stakeholders on improving their services. 
Based on the ICC Reports and clients' and stakeholders' feedback, DPMO regularly reviews the ICC operation in terms of activities conducted and costs incurred. Importantly, the ICC was initiated as the pilot project for the period up until the end of 2018 (Metodický pokyn č. 25 Methodology Guidance no. 25, 2018). During this period project had to demonstrate fulfillment of the two formal criteria. First, meeting the value of the measurable indicator expressed as the total number, six founded ICC (Zmluva o poskytnutí č. 750/2016 - Grant Award Agreement no. 750/2016) and the second, reported stakeholders' positive feedback representing ESIF management and implementation bodies as well as ICC clients. Only then, the contract is renewed for the period up until the end of the programming period in 2023 (Zmluva o poskytnutí č. 1311/2019 - Grant Award Agreement no. 1311/2019).

On top of monitoring the ICC activities via their reports, DPMO is entitled to terminate operations of any ICC in the following instances (Methodology Guidance no. 25, 2019):

- if at least half of the Managing Authorities or ICC clients formally express their dissatisfaction in regular surveys or biannual reports;

- ICC has no employees for the period exceeding one month;

- a given municipality hinders its ICC operation e.g. by disabling trainings for staff or it does not create a dedicated website;

- ICC does not follow DPMO Guidance even after receiving an email notification from the DPMO urging compliance.

As Table 1 shows, the ICC demonstrates measurable activities representing quantifiable results between July 2016 and June 2020. These figures enable some interesting findings. Firstly, the ICC does not spend as much as they are entitled. This shows that the budget does constrain ICC operations and they can quite easily provide their service portfolio within the given financial limits. Secondly, their activities combine the reception of clients and office work (expressed as consultations and emails in Table 1) in their premises and off-the-premises (to some extend expressed as workshops and contacts in Table 1). It is however difficult to determine which of the two types of activities (if any at all) has a decisive impact on submission of grant applications and their successful awarding. Thirdly, even tough, there is no fact-proven direct linkage between services provided on one side and submission of grant applications and their awarding on the other side, it is certainly an interesting fact of a relatively high percentage rate of grant awards linked to applications which were preceded by consultations in the ICC.

Table 1. July 2016 - June 2020 report

\begin{tabular}{|l|c|}
\hline \multicolumn{1}{|c|}{ Type of indicator } & Value \\
\hline Number of consultations & 6508 \\
\hline Number of contacts acquired & 4716 \\
\hline Number of workshops conducted & 16931 \\
\hline $\begin{array}{l}\text { Efficiency (expressed as \% of total available running costs } \\
\text { needed to ensure full operation) }\end{array}$ & $65 \%$ \\
\hline Number of emails sent aimed at information dissemination & 2805 \\
\hline Number of grant applications from clients & 3509 \\
\hline Percentage of successful applications & $<70 \%$ \\
\hline
\end{tabular}

Source: Sumárna správa [Summary Report], 2020 


\section{INTERPRETING ICC VIA THE P-A FRAMEWORK}

As stated in the previous part, improving visibility and awareness of EU funding opportunities at regional level constitutes a legitimate ground for identifying a proper improvement measure on the part of the state administration such as founding the ICC. Two important findings can be derived here with an impact on the P-A relations. Firstly, there are no pre-existing public services and organisational structures to address identified gaps. This means a brand-new solution should have been devised. An obvious Government ambition is to launch a project which shows to be successful in terms of providing a change. At a minimum, this means setting up services which in the eyes of stakeholders demonstrate some relevance. Secondly, EU funds are a synonym for successful EU membership. Thus, the EU grants have a direct impact on citizens' perceived quality of membership and formation of pro-European sentiments. Both phenomena, funds absorption and pro-EU sentiments are politically sensitive falling under the Government's responsibility which obviously seeks solutions to achieve both.

The Government attempts its best to stimulate new grant applications and increase their awarding by creating necessary institutional arrangements such as founding the ICC. However, even with reported stakeholders' positive recognition of the ICC services, there is currently no evidence that an increase in applications and their awards is in hands of the Government/ICC. This means that even if the Government does hypothetically everything correctly, fund absorption and pro-EU sentiments may not have a corresponding increase as there is no direct correlation demonstrated so far. Conversely, without ICC, absorption and pro-EU sentiments may not decline. A politically sensitive context is an unavoidable fact determining Government actions as the principal. Similarly, ICC as the agent, being also a public administration actor, is also familiar with this context. Both are thus facing uncertainty costs in the form of reputation risk as outlined before. This perspective sheds new light on the P-A relations.

Traditionally, delegation and control as the building components predetermine P-A interactions. The principal delegates and to minimize negative consequences of information asymmetry and consequent agency slack, he also puts in place control mechanisms including punitive means to intimidate the agent including a threat of a withdrawal of the delegation mandate. Thus, dynamics of P-A relations is built around a permanent tension stemming from their divergent interests and mutual distrust. To demonstrate control system's efficiency, there are instances of activating punitive mechanisms. The contrary is traditionally interpreted as agent's extraordinary autonomy or a nearly perfect control system. As Epstein and O' Halloran (1999) put it in case of the latter: "If the mere threat of [principal] retaliation is enough to cow [...] agents into submission, then these agents will never step out of line and [principals] need never impose any overt sanctions. Thus, the traditional tools of control may be so effective that they are never actually used" (p.24). However, neither of the two (agent's extraordinary autonomy or a nearly perfect principal's control system) can explain rather a smooth ICC operation.

There are two possible and mutually reinforcing interpretations for rather non-conflicting P-A relations stemming from the above outlined political context and the shared P-A interest to minimise uncertainty costs. Firstly, leaving punitive means aside does not necessarily represent their sufficiently deterring nature or principal's passivity/agent's autonomy. Instead, it may show agent's skill to anticipate principal's interest. For example, Table 1 shows operational efficiency meaning ICC can do much more with spending much less while achieving still increasing overall stakeholders' satisfaction (Sumárna správa - Summary Report, 2019, p. 15). So, even if direct oversight mechanisms also called "police patrol" (McCubbins and Schwartz 
1984) are in place, due to converging interests the agent acts unison with the principal's goals. Such situation is referred in the P-A scholarship as observational equivalence (Pollack, 2002; Damro, 2007; Delreux and Adriaensen, 2017). A reply to the obvious questions how specifically is observational equivalence manifested in our context constitutes the second interpretation of the non-conflicting P-A relations.

As depicted in the previous part, the ICC bindingly report on the set of indicators, however with no predefined values. This means that the ICC reports more on activities than on results. The actual achievements (specific values of indicators) thus are solely a result of the ICC individual and unregulated performance while the interpretation of their performance is the Government unique competence as the principal and this exercise is inevitably subjective. As both public administration actors' function in a highly political context, they mutually align their goals. Their shared interest is to minimize uncertainty costs meaning not to jeopardize their reputation. Thus, instead of conflict over reporting and its evaluation, the agent and the principal opt for cooperation based on a tacit agreement with the steps of the other actor provided stakeholders' feedback remains positive. Thus, agent's reporting as well as principal's monitoring and evaluation show to be guided by ceremonialism. The P-A scholarship associates ceremonialism with agent's strategy of resisting principal's monitoring (Hawkins and Jacoby, 2009). However, with the shared goals and a common reputation securing strategy, ceremonialism can well explain also principal's conduct. Importantly, ceremonialism does not necessarily infer (though it may) that the P-A performance is merely guided by sheer and superficial formalism. Instead, a prevailing mutual cooperative mode in the P-A relations is an underlying motive, shaping dynamics of their interactions with beneficial effects for both.

Observational equivalence and ceremonialism show that the overall political context is decisive for dynamics of the P-A relations. In the end, however, a missing mutual conflict is not detrimental to the mission of stimulating a grass-rooted EU funds consultancy and information dissemination. Instead, a cooperative mode contributes to fostering partnership ties between the state and municipal actors which are in the end beneficial for both. Their cooperation enables them to minimize uncertainty costs, notably their individual reputation risk and achieve stakeholder's satisfaction. Evidence of the success of this strategy is the formalized Government's commitment to continue with the territorial consultancy and information dissemination services also in years to come.

\section{CONCLUSION}

The paper presents a consistent analysis of the ICC operations via the P-A framework with noteworthy findings relevant for studying the limits of the P-A framework. The major finding of the paper suggests that the cooperative mode between the ICC and the Government dominantly shapes the dynamics of the P-A relations rather than their mutual conflict. In this respect, observational equivalence and ceremonialism are the two underlying interpretative tools providing explanations for understanding the P-A concerted relation. However, these tools have a limited explanatory power in the paper. The reason is that they address dynamics of the P-A relations as only being determined by the overall political context. This is on the one hand necessary, and on the other, it limits the scope of the research on official releases of both actors. Then we know little how their interactions are shaped notably by a broader portfolio of stakeholders. Such a methodological pitfall can only be addressed by generating additional data from stakeholders through qualitative research methods as structured interviews or questionnaires. Furthermore, interpreting P-A concerted relations stemming from the shared 
goals and interests as determined by the political context shows also limits of the P-A framework to provide more in-depth functional analysis of public administration. Similarly, such an analysis, going beyond the official releases, would also enable to examine the ICC as a collective rather than unitary agent as is the case of the present paper.

\section{ACKNOWLEDGEMENT}

"This contribution was supported by VEGA grant no. 1/0605/19."

\section{REFERENCES}

Bache, I. (1999). The extended gatekeeper: Central government and the implementation of EC regional policy in the UK. Journal of European Public Policy, 6(1), 28-45.

Bache, I. (2010). Partnership as an EU policy instrument: A political history. West European Politics, 33(1), 58-74.

Bachtler, J. and McMaster, I. (2008). EU cohesion policy and the role of the regions: investigating the influence of structural funds in the new member states. Environment and Planning, C 26(2), 398-427.

Bachtler, J. and Ferry, M. (2013). Conditionalities and the performance of European structural funds: A principal-agent analysis of control mechanisms in European Union cohesion policy. Regional studies, (49)8, 1258-1273.

Barca, F. (2009). An agenda for a reformed cohesion policy. A place-based approach to meeting European Union challenges and expectations. Independent report prepared at the request of Danuta Hübner, Commissioner for Regional Policy, Brussels.

Bauer, M. (2002). The EU "partnership principle": still a sustainable governance device across multiple administrative arenas? Public Administration, 80(4), 769-89.

Blom-hansen, J. (2005). Principals, agents, and the implementation of EU cohesion policy. Journal of European Public Policy, 12(4), 624-648.

Commission Delegated Regulation (EU) No 240/2014 on the European code of conduct on partnership in the framework of the European structural and investment funds. Official Journal of the European Union.

Damro, C. (2007). EU delegation and agency in international trade negotiations: A cautionary comparison. Journal of Common Market Studies, 45(4), 883-903.

Delreux, T. and Adriaensen, J. (2017). Introduction. Use and limitations of the principal-agent model in studying the European Union. In T. Delreux and J. Adriaensen (Eds.) The Principal Agent Model and the European Union. (pp. 1-34). Cham: Palgrave Macmillan, Palgrave Studies in European Union Series. https://doi10.1007/978-3-319-55137-1

Dür, A. and Elsig, M. (2011). Principals, agents, and the European Union's foreign economic policies. Journal of European Public Policy, (18)3, 323-338

Epstein, D. and O'Halloran, S. (1994). Administrative procedures, information, and agency discretion. American Journal of Political Science, 38(3), 697-722.

Hawkins, G. D. and Jacoby, W. (2009). How agents matter. In D. G. Hawkins, D. A. Lake, D. L. Nielson, and M. J. Tierney (Eds.) Delegation and Agency in International Organizations. Cambridge: Cambridge University Press. https://doi.org/10.1017/CBO9780511491368

Kassim, H. and Menon A. (2003). The principal-agent approach and the study of the European Union: promise unfulfilled? Journal of European Public Policy. 10(1), 121-139.

Metodický Pokyn č. 25, verzia 3 (2018) [Methodology Guidance no. 25, version 3]. Centrálny koordinačný orgán, c, Bratislava. 
Metodický Pokyn č. 25, verzia 4 (2019) [Methodology Guidance no. 25, version 4]. Centrálny koordinačný orgán, Úrad podpredsedu vlády SR pre investície a informatizáciu, Bratislava.

McCubbins, M. D. and Schwartz, T. (1984). Congressional oversight overlooked: police patrols versus fire alarms. American Journal of Political Science, 28, 165-179.

Moe, T. (1984). The New Economics of Organization. American Journal of Political Science, 28 (4), 739-777.

Perrow, C. (1986). Economic theories of organization. Theory and Society, 15, 11-45.

Pollack, M. A. (1997). Delegation, Agency, and agenda setting in the European Community. International Organisation, 51 (1), 99-134

Pollack, M. (2002). Learning from the Americanists (again): Theory and method in the study of delegation. West European Politics, 25(1), 200-219.

Polverari, L. and Michie, R. (2009). New partnership dynamics in a changing cohesion policy context. IQ-Net Thematic Paper, 25(2), 1-86.

Programové vyhlásenie vlády Slovenskej republiky na obdobie rokov 2020 - 2024, Uznesenie vlády č. 239/2020. (2020) [Manifesto of the Government of the Slovak Republic 20162020, Government Resolution No. 239/2020].

Shavel, S. (1979). Sharing and incentives in the principal and agent relationship. The Bell Journal of Economics. 10(1), 55-73.

Sobol, M. (2015). Principal-agent analysis and pathological delegation: The (almost) untold story. Governance: An International Journal of Policy, Administration, and Institutions. (29)3, 335-350

Sumárna Správa o Činnosti Informačno-poradenských Centier za obdobie od 1.7. do 31.12.2019 (2019). [Summary report on activities of Information and Consultancy Centres between 1 July and 31 December 2019]. Úrad podpredsedu vlády SR pre investície a informatizáciu, Bratislava

Sumárna Správa o Činnosti Informačno-poradenských Centier za obdobie od 1.1. do 30.6.2020 (2020). [Summary report on activities of Information and Consultancy Centres between 1 January and 30 June 2020]. Ministerstvo investícií, regionálneho rozvoja a informatizácie SR, Bratislava.

Zhodnotenie Administratívnej Zát'aže na Strane Žiadatel'ov a Prijímatel'ov v Procese Implementácie Pomoci z Fondov EÚ v Programovom Období 2007-2013. (2013). [Assessing Administrative Burden on the Part of Applicants and Beneficiaries in the Process of Implementing EU Funds in the Programming Period 2007-2013]. Úrad vlády SR, Bratislava.

Zmluva o Poskytnutí Nennávratného Finančného Príspevku č. 750/2016 (2016). [Grant Award Agreement no. 750/2016] https://www.crz.gov.sk/data/att/2593386_dokument1.pdf

Zmluva o Poskytnutí Nennávratného Finančného Príspevku č. 1311/2019 (2019). [Grant Award Agreement no. https://www.crz.gov.sk/data/att/4371853_dokument1.pdf

1311/2019] 